\title{
Phylogenetic Analysis of Striped Hyaena (Hyaena hyaena: Hyaenidae, Carnivora) in Hatay Province in Turkey
}

\author{
Erol Atay ${ }^{1, a, *}$, Mustafa Ersal ${ }^{2, b}$, Kemal Karabağ ${ }^{3, c}$, İsmail Turan Çetin ${ }^{4, d}$ \\ ${ }^{1}$ Department of Biology, Faculty of Arts and Sciences, Mustafa Kemal University, 31060 Hatay, Turkey \\ ${ }^{2}$ Institute of Science, Akdeniz University, 07070 Antalya, Turkey \\ ${ }^{3}$ Department of Agricultural Biotechnology, 07070 Akdeniz University, Antalya, Turkey \\ ${ }^{4}$ Institute of Science, Mustafa Kemal University, 31060 Hatay, Turkey
}

*Corresponding author

\begin{tabular}{l|l}
\hline A R T I C E I N F O & A B S T R A C T \\
\hline Research Article & $\begin{array}{l}\text { Striped hyaena (Hyaena hyaena) is one of the species in danger of extinction and categorized globally } \\
\text { as "Under Threatened Organism". From time to time, different tissue samples and carcasses of the } \\
\text { striped hyena are reported in different regions of Anatolia. In this study, 571 bp length of Cytochrome } \\
\text { C Oxidase Subunit II (COX 2) of mitochondiral DNA from hair, ears, nails and teeth specimens from } \\
\text { six striped hyaenas were amplified and sequenced to determined phylogenetic relationships between } \\
\text { close and distant species related to hyaena. Tissue samples using in this study were found randomly } \\
\text { at different times in Hatay province, Turkey. According to our results, all colected samples located } \\
\text { in Hatay region are the members of H. hyaena species. Moreover, this research is the first molecular } \\
\text { Accepted : } 16 / 06 / 2021 \\
\text { research using COX2 gene region for phylogenetic analysis in Turkey. Further investigation can be } \\
\text { performed on studies that suggest determining phylogenetic status of striped hyaenas. }\end{array}$ \\
Keywords: &
\end{tabular}

Carnivora

COX 2

Hyaena hyaena

Hyaenidae

Striped Hyena

Türk Tarım - Gıda Bilim ve Teknoloji Dergisi, 9(6): 1047-1052, 2021

\section{Hatay İlinde Çizgili Sırtlanın (Hyaena hyaena: Hyaenidae, Carnivora) Filogenetik Analizi}

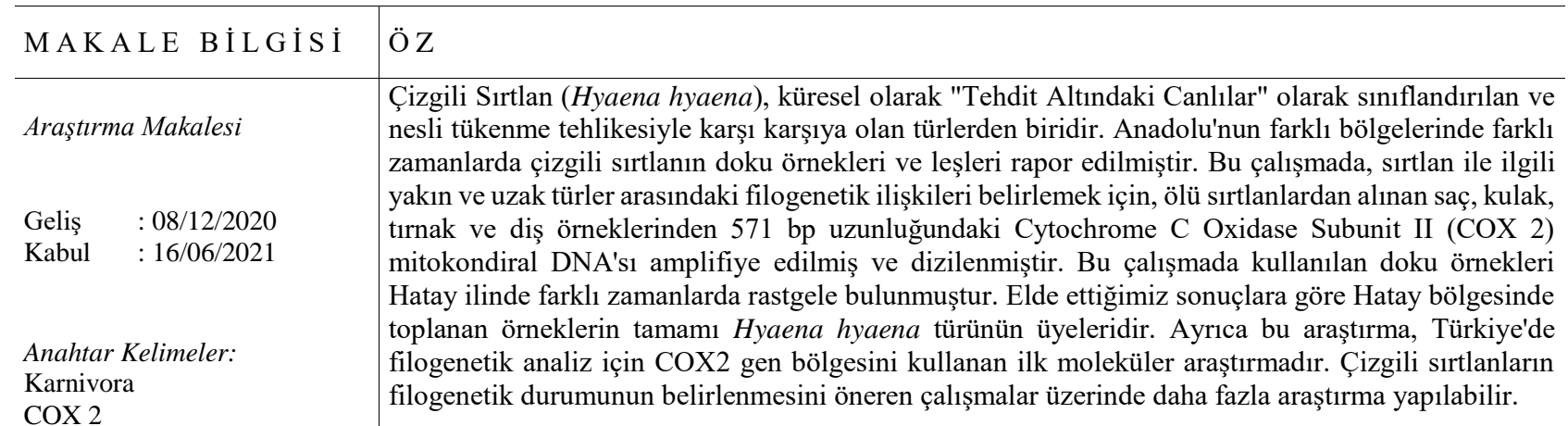

COX 2

Hyaena hyaena

Hyaenidae

Çizgili Sırtlan 


\section{Introduction}

Turkey, a natural land bridge linking Europe and Asia, has hosted countless mammalian species such as the striped hyaena historically (Johnson, 2002). Among them, the striped hyaena is a member of the Hyaenidae family and is one of the smallest family of the Carnivora. Biochemical and paleontological data indicate that hyaenas originated from stem feliforms in Late Oligocene approximately 25 million years ago. (Bernor et al., 1996). Hyaenas have reached their highest diversity with 20-30 species during the Late Miocene period (Werdelin and Solounias, 1991). However, after this period, it gradually decreased and only 4 species have survived (Brown and Lomolino, 1998; Simpson, 1953). Thus, the four existing species are considered taxonomic residues, which were once the remains of a different group (Koepfli et al., 2006). Striped hyaenas are often seen ecologically as garbage collectors of nature, just like vultures, as they feed on carcasses at night. In order to maintain ecological balance, striped hyaenas should be taken under protection as soon as possible.

The striped hyaena (Hyaena hyaena Linnaeus, 1758) is a group of carnivores that has a widespread range compared to other hyaenas. Although the general appearance of hyaenas associates them with the dog family (Kruuk, 1976; Prater, 1971), the structure of the skull, teeth and other anatomical features makes them members of the Feliformia group which is the lower order of Carnivora (Alam et al., 2015).

The distribution of the H. hyaena populations, as shown in Figure 1, comprises most of Africa (except for the southern parts), the Middle East including the Arabian Peninsula, Turkey, the Levant, Iraq, Iran and the Caucasus (Armenia, Azerbaijan, Georgia), and extends further into Central Asia and the Indian subcontinent (Kasparek et al., 2004). In general, $H$. hyaena species inhabit like other hyaena species in geographic areas such as steppes, rocky terrain, and sparse tree valleys (Mills and Hofer, 1998). In the last 25 years, a limited number of striped hyaena (Hyaena hyaena) species recorded in Anatolia, Çan (Çanakkale province), Bergama (Kozak Plateau and Yuntdağ region), Lake Bafa / Milas, Antalya (Termessos National Park), Bolkar Mountains, Amanos Mountains (Hatay province) and Southeast Anatolia regions.

Striped hyaenas are called primary scavengers. The main food sources of hyaenas are the dried meats and bones of vertebrate carcasses that are too large for them to hunt. Likewise, they also meet their nutritional needs by hunting smaller vertebrates (Kruuk, 1976). Adult striped hyaenas weigh approximately 30-35 kilograms and generally feed on their own. In this species, male individuals are slightly larger than female individuals and are found to be more socially dominant than females (Watts and Holekamp, 2007). In addition, small groups of one adult female and several adult males share a common burrow area and usually rest together during the daylight hours (Wagner, 2007).

Mills and Hofer (1998) stated that there is an evidence of the extinction of hyaenas in many places and that the hyaena population generally is quite low. Considering that the molecular information about $H$. hyaena is insufficient in the literature and the number of these animals is decreasing day by day, it is important to carry out studies in this field. In addition, the importance of striped hyaena species members will be understood by scientists as a result of genetically identified phylogenetic analyses using mitochondrial gene regions.

The mitochondrial genome is a very useful tool for phylogenetic analysis (Avise, 1994). The study of mitochondrial DNA (mtDNA) makes it possible to generate data for population structure, gene flow, hybridization, biogeography, and phylogenetic relationships (Moritz, 1994). Since mtDNA genes can evolve faster than many other nuclear genes, it is a suitable molecular tool for the analysis of phylogenetic relationships of close relatives species and populations (Presa et al., 2002). In addition, the control region of mtDNA is highly variable and can vary even among individuals. This region contains sequential repeats in many cases. Because of these features, it is used in phylogenetic studies among species, subspecies, and populations (Zhang and Hewitt, 1997).

In this study, it was aimed to demonstrate the phylogenetic relationships of $H$. hyaena members in Hatay region representing close and distant relatives of the hyaena population in Anatolia.

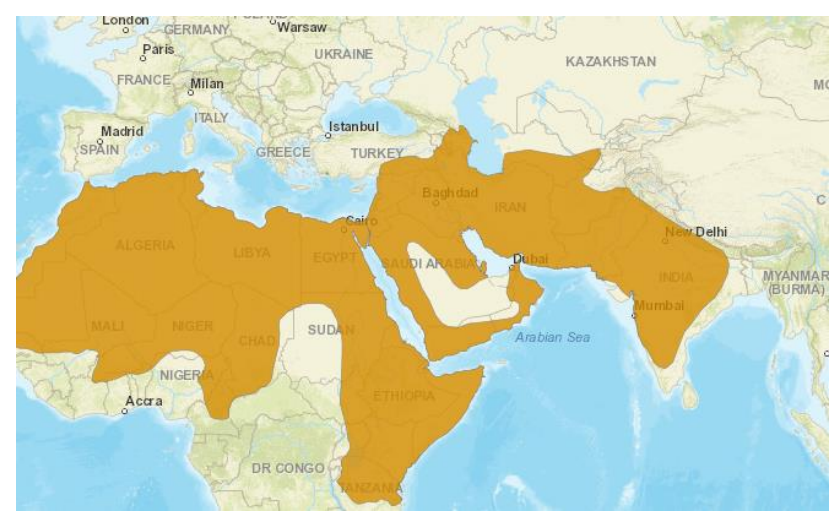

Figure 1. The distribution areas of $\mathrm{H}$. hyaena populations (AbiSaid and Dloniak, 2015).

\section{Materials and Methods}

\section{Sample Collection}

Tissue pieces such as feather, ear, nail, and teeth of the Anatolian hyaena (Hyaena hyaena) were obtained from six dead animals at the Hatay region. The samples were stored in absolute ethanol at $-80^{\circ} \mathrm{C}$.

\section{DNA Extraction and PCR Procedure}

For each individual, $25 \mathrm{mg}$ of tissue samples (feather, ear, nail, and tooth) were mechanically disintegrated with the aid of liquid nitrogen. After extraction of genomic DNA, the quality and quantitation values of the obtained DNA samples were measured on the BioDrop instrument. The extracted samples were stored at $-20^{\circ} \mathrm{C}$ for further studies. Subsequently, tissue samples were used to extract genomic DNA using the Cells and Tissue DNA Isolation Kiti (53100-NORGEN), following the manufacturer's instructions. To amplify fragments of the mtDNA, we performed the following procedures: 
Amplification of COX2 gene: Specific primers (FTGGGCAAGCTGTGG, R-TCCAGGACGCTTCC) were designed in the Primary-Blast software using current (www.ncbi.nlm.nih.gov) H. hyaena mitochondrial Cytochrome C Oxidase Subunit II (COX2) gene sequence information. The specificity of the designed primers was checked in the NCBI database. PCRs (Polymerase Chain Reactions) were performed in $20 \mu \mathrm{L}$ for the primer pair as follows: $10 \times$ PCR Buffer: $2 \mu \mathrm{L} ; \mathrm{MgCl}_{2}(25 \mathrm{mM}): 2 \mu \mathrm{L}$, dNTPmix (10 mM): $2 \mu$, forward primer $(25 \mathrm{pM} / \mu \mathrm{l}): 0.2$ $\mu \mathrm{L}$, reverse primer $(25 \mathrm{pM} / \mu \mathrm{l}): 0.2 \mu \mathrm{L}$, Taq DNA polymerase (Sigma-Aldricht): $2 \mu \mathrm{L}$, template DNA: $1 \mu \mathrm{L}$ and $11.9 \mu \mathrm{l}$ of RNAse-free water $\left(\mathrm{dH}_{2} \mathrm{O}\right)$. Thermocycling parameters were set at predenaturation of one cycle at $94^{\circ} \mathrm{C}$ for $2 \mathrm{~min}$, followed by 30 cycles of denaturation at $94^{\circ} \mathrm{C}$ for $30 \mathrm{~s}$, annealing at $54^{\circ} \mathrm{C}$ for $35 \mathrm{~s}$, extension at $72^{\circ} \mathrm{C}$ for $45 \mathrm{~s}$ and ending with an extension at $72^{\circ} \mathrm{C}$ for $5 \mathrm{~min}$.

Agarose gel electrophoresis of $2 \%$, which was stained with $1 \mu$ l of ethidium bromide, was used to detect the presence of total DNA and the amplification in the PCR process. The electrophoresis was carried out at 70 volts for 45 minutes. The sequencing of amplified fragments of the COX2 gene region was performed by the relevant company.

Phylogenetic analysis: Sequence results of six striped hyaena samples collected in the Hatay region were checked by using the FINCH TV software (available from https://finchtv.software.informer.com/1.4/) to a state of the peaks of the base sequences. Verified sequences were checked by performing BLAST in the NCBI (www.ncbi.nlm.nih.gov) database. The mtDNA COX2 (571 bp) sequences of samples were edited and aligned by using Geneious Prime software (available from https://www.geneious.com/prime/).

The sequences of the hyaena samples obtained from Hatay region were aligned to consensus using the GENEIOUS program. Afterward, the phylogenetic tree was rooted by Align by ClustalW process using the MEGA 7.0 program (Kumar et al., 2016). Neighbor-joining method was used to generate a phylogenetic tree by 1000bootstrap. The red fox, Vulpes vulpes (Accession numbers: JN711443) and the Eurasian lynx, Lynx lynx (Accession numbers: KR132581) were used as outgroup (Table 1). With a similar context, DnaSP v. 5.10 .01 (Librado and Rozas, 2009) was used to determine genetic variability parameters such as haplotype number (n), haplotype diversity $(\mathrm{Hd})$, and nucleotide diversity $(\mathrm{Pi}, \pi)$. On the other hand, the median-joining (MJ) method, which was executed in the software NETWORK version 5.0.0.3 (http://www.fluxus-engineering.com) (Bandelt et al., 1999), was used to determine the relationship between the Anatolian striped hyaena and other species haplotypes (Figure 4).

Table 1. A list of the determined other species for phylogenetic relations with Anatolian striped hyaenas in this study.

\begin{tabular}{l|llll}
\hline \multicolumn{1}{c|}{ Species name } & \multicolumn{1}{c}{ Locality } & Sequence length, bp & Accesion number & Literature \\
\hline Hyaena hyaena & France & 683 & JF894376 & Bon et al., 2012 \\
Crocuta crocuta & France & 683 & KU937361 & Palacio et al., 2017 \\
Parahyaena brunnea & Southern Africa & 683 & MF593946 & Westbury et al., 2018 \\
Proteles cristata & Southern Africa & 683 & MH662444 & Westbury et al., 2019 \\
Vulpes vulpes & Korea & 683 & JN711443 & Yu et al., 2012 \\
Lynx lynx & Germany & 683 & KR132581 & Paijmans et al., 2016 \\
\hline
\end{tabular}

\section{Results and Discussion}

In the current study, to investigate genetic variability and differentiation of Anatolian hyaena, tissue samples were collected from roadkill striped hyaenas in the Hatay region, Turkey. In this context, sequences of mtDNA gene, $571 \mathrm{bp}$ of COX2, were successfully amplified from six individuals of Anatolian striped hyaenas.

The phylogenetic analysis was performed in order to determine the genetic distance between Anatolian striped hyaenas and other hyaenas populations. For this purpose, molecular analyses were performed by designing primers that are specific to the mitochondrial COX2 gene region. Successful amplification was obtained from all striped hyaena samples by using PCR. On the other hand, a negative control group was used to determine contamination and / or false amplification. This approach increased the reliability of the results. In addition, $571 \mathrm{bp}$ fragments of the mtDNA COX2 gene amplified from extracted genomic DNA of our samples which belongs to six individuals of the Anatolian striped hyaena (Hyaena hyaena) in Hatay region are shown in Figure 2.

The result of phylogenetic analysis of the amplified COX2 gene region using PCR application for each sample is visualized in Figure 3. According to the results of phylogenetic analysis, it was determined that our samples showed $100 \%$ similarity to each other, and $H$. hyaena was the most closely related species to our samples. Furthermore, in contrast to the cytochrome b (Cyt b) gene commonly used in other studies as a target region, this is the first research that using COX 2 gene as the target region for phylogenetic analysis of the striped hyaena in Turkey.

The genetic variability parameters of the striped hyaena specimens in the Hatay region were arranged by DnaSP analysis. According to the results, it was understood that the number of variable sites value was $381 \mathrm{bp}$. Furthermore, genetic variability parameters of our samples for COX2 gene were displayed in Table 2, including sample size (n), sequence length (bp), haplotype number $(\mathrm{n})$, haplotype $(\mathrm{Hd})$ and nucleotide diversities $(\mathrm{Pi}, \pi)$, and pairwise Fst data. As a result of haplotype analysis, our samples were formed a single haplo-group. On the other hand, each of the outgroup samples was separated. For this reason, the number of haplotypes was determined as seven. When compared to the mtDNA sequences of COX2 gene region of the outgroup species (see Table 1), our samples, that have unique haplotypes, had relatively a regional difference. The drawing obtained as a result of network analysis is given in Figure 4. 
Table 2. Genetic variability parameters for mitochondrial data set (COX 2) of the Anatolian striped hyaena and other species.

\begin{tabular}{l|c}
\hline \multicolumn{1}{c|}{ Variability parameters } & Value \\
\hline Data set & COX 2 \\
Sample size, $\mathrm{n}$ & 12 \\
Sequence length, bp & 381 \\
Haplotype number, $\mathrm{n}$ & 7 \\
Haplotype diversity, Hd & 0.7727 \\
Nucleotide diversity, Pi, $\pi$ & 0.35293 \\
Pairwise Fst & 1.0000 \\
\hline
\end{tabular}

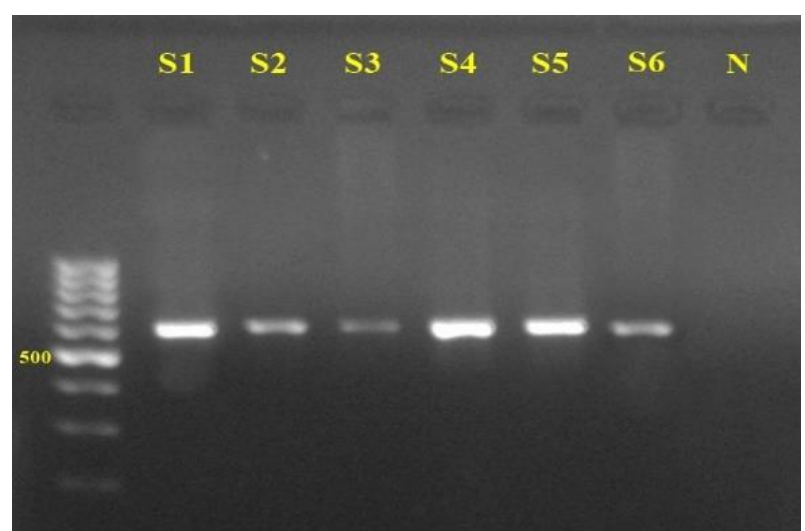

Figure 2. PCR products of Anatolian striped hyaenas obtained in Hatay region (S: Sample of an Anatolian striped hyaena, N: negative control).

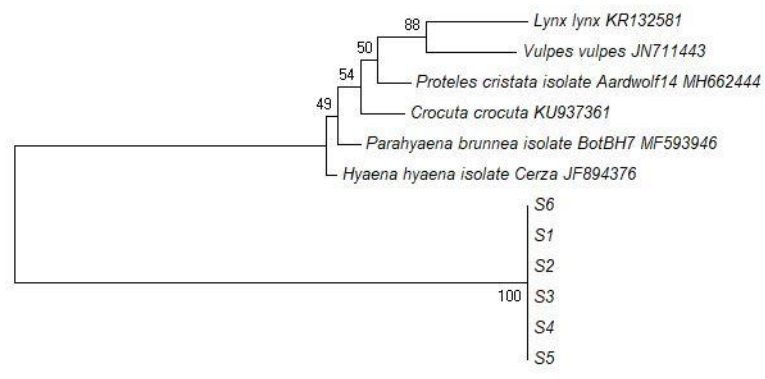

$\longmapsto 0.1$

Figure 3. The result of the phylogenetic analysis of $\mathrm{H}$. hyaena species in Hatay province (S1-S6: Anatolian striped hyaena samples).

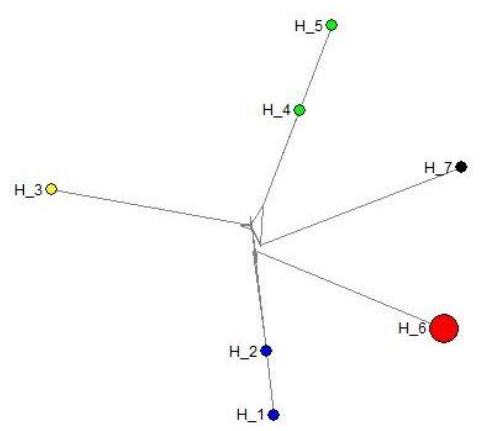

TURKEY

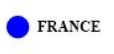

AfRICA

GERMANY

KOREA

Figure 4. Median-joining network constructed by using the mitochondrial COX 2 haplotypes (345 bp) of the Anatolian H. hyaena and other species.
The Anatolian part of Turkey is a contact region of three biodiversity hotspots that are known as Caucasus, Iran-Anatolia, and Mediterranean, and it has high endemism for a great number of species due to topographic structure and climatic differences (Bilgin, 2011; Şekercioğlu et al., 2011). Therefore, it is possible to obtain information about the evolution processes or origins of the species using mtDNA in the Anatolian region. Although the animal mtDNA was selected as the target region for this study consists of 37 genes, since it is inherited as a single unit and the evolution process of a single gene will be different from the evolutionary process of the whole genome, it is thought that there may be a higher margin of error in the evaluation of phylogenetic trees generated using mtDNA (Avise, 1994). For these reasons, it is considered that the use of nuclear and mitochondrial genes together in phylogenetic analysis and testing their phylogeographic compatibility may be appropriate way to obtain more accurate results (Avise, 2000). Therefore, the obtained data in this study should be compared with the data of nuclear DNA regions in further studies.

In the study conducted by Akay et al. (2011), it was aimed to monitor and evaluate the spread of striped hyaena species in Altınözü, Hatay province. For this purpose, geographic information systems (GIS) database and remote sensing technologies used in ArcGIS 9.2 program were used. As a result of the study, the total area of the distribution of striped hyaenas in the Altınözü area was calculated as 38,097 hectares. In addition, poultry and organic wastes were identified as the main food sources of striped hyaenas. This proves the existence of a striped hyaena population in Hatay province, Turkey.

Bon et al. (2012) reported that DNA samples belonging to hyaena species were sequenced targeting the Cyt $\mathrm{b}$ mitochondrial DNA region with the using fossilized fertilizer fragments in Coumère, France. As a result of phylogenetic analysis of the CC8 and CC9 coded samples used in the study, the closest relatives were identified as Crocuta crocuta and $H$. hyaena. This result shows a high similarity with the result obtained in our study.

According to another research which was studied by Schramme (2015), fecal samples of hyaenas were used as genomic DNA sources in the molecular analysis method which was carried out to determine the distribution of spotted hyaena ( $C$. crocuta) species in northern Ethiopia region of Mekelle. It was investigated whether the DNA samples of spotted hyaena species differed with other hyaena populations at molecular level. As a result of the molecular analysis, no genetic differentiation was observed for spotted hyaena samples in the Mekelle region. This shows that spotted hyaenas are members of the same group (Schramme, 2015). In our study, we did not find any phylogenetic differences among our samples which were obtained in Hatay province. Hence, it is understood that hyaena communities maintain their lives in separate groups.

Atay et al. (2017) reported that striped hyaenas were wandered around and lived in Şanlıurfa and Hatay regions (Syrian border). Furthermore, it was determined that they were observed more frequently both in the barren area and close to poultry farms which are located in Hatay province. The Cty b mitochondrial DNA region isolated from hair, ear and carcass tissues was used for molecular 
characterization of striped hyaena samples in this region. According to the result of the molecular analysis, it was found that Cyt b mitochondrial DNA sequences of samples were similar to eachother. In addition, the sequences have been shown to be highly conserved among the $H$. hyaena species of the Cty $\mathrm{b}$ gene as compared to previously reported related studies. The results obtained in our study revealed that although a different mitochondrial DNA region was used as the target region, there was no intraspecies difference in molecular characterization and the target gene region was preserved.

According to the phylogenetic dendrogram analysis applied in our study, the species of H. hyaena is showed closest relatives species to the striped hyaena samples which were found in the Hatay region (Bon et al., 2012). However, it can be assumed that there may be a migration of thousands of kilometers for striped hyaenas located in the Hatay region and they preserved their genetic structure at the mitochondrial DNA level (Rohland et al., 2005). In this regard, to obtain a certain result, a more comprehensive study is needed, such as both morphological and molecular analyses.

In conclusion, this study provides the first genomic data set using the COX2 mitochondrial gene region for molecular characterization of the striped hyaena species in Turkey. Despite not having enough data due to a small number of mtDNA haplotypes and the Anatolian striped hyaena samples, the current study presented has a meaningful data to contribute to elucidating the genetic structure of the Anatolian striped hyaenas. Furthermore, this study shows that the hyaena species and their coprolites and possibly other carnivore species deserve special attention for paleogenomics studies. Turkey is very rich in terms of biodiversity, especially due to climatic and geographical location. Unfortunately, the striped hyaena facing the danger of extinction has not been given the necessary attention in Turkey. It is believed that this study will contribute to the identification and investigation of the Anatolian striped hyaena species.

\section{Acknowledgements}

We wish to thank HMKU Scientific Research Projects Coordinator (BAP) (Project Number 19.YL.027) at Hatay Mustafa Kemal University and Doğa Derneği (Birdlife Turkey).

\section{References}

Abi-Said M, Dloniak, SMD. 2015. Hyaena hyaena. The IUCN Red List of Threatened Species 2015: e.T10274A45195080.

Akay A, Inac S, Yildirim IC 2011. Monitoring the local distribution of striped hyaenas (Hyaena hyaena L.) in the Eastern Mediterranean Region of Turkey (Hatay) by using GIS and remote sensing technologies. Environmental monitoring and assessment, 181: 445-455. DOI: 10.1007/s10661-010-1840-6.

Alam MS, Khan JA, Pathak BJ. 2015. Striped hyaena (Hyaena hyaena) status and factors affecting its distribution in the Gir National Park and Sanctuary, India. Folia Zoologica, 64: 32 40. DOI: 10.25225/fozo.v64.i1.a4.2015.

Atay E, Kasapoğlu A, Çetin İT. 2017. Status of Striped Hyaena (Hyaena hyaena) in Hatay and Şanlıurfa-Turkey. Turkish Journal of Agriculture-Food Science and Technology, 5: 1165- 1172. DOI: 10.24925/turjaf.v5i10.1165-1172.1295.
Avise JC. 1994. Molecular markers, natural history and evolution. NY: Chapman and Hall. pp. 511.

Avise JC. 2000. Stability, equilibrium and molecular aspects of conservation in marine species. Marine Genetics, xi-xii.

Bandelt HJ, Forster P, Röhl A. 1999. Median-joining networks for inferring intraspecific phylogenies. Molecular biology and evolution, 16: 37-48.

Bernor RL, Fahlbusch V, Mittmann HW. 1996. The evolution of western Eurasian Neogene mammal faunas. Columbia University Press. ISBN: 0231082460, 9780231082464.

Bilgin R. 2011. Back to the suture: the distribution of intraspecific genetic diversity in and around Anatolia. International Journal of Molecular Sciences, 12: 4080-4103. DOI: 10.3390/ijms 12064080 .

Bon C, Berthonaud V, Maksud F, Labadie K, Poulain J, Artiguenave F, Elalouf JM. 2012. Coprolites as a source of information on the genome and diet of the cave hyaena. Proceedings of the Royal Society B: Biological Sciences, 279: 2825-2830. DOI: 10.1098/rspb.2012.0358.

Brown JH Lomolino MV. 1998. Biogeography. 2nd Ed. Sunderland, Massachusetts (Sinauer Associates, Inc. Publishers).

Johnson K. 2002. The status of mammalian carnivores in Turkey. Endangered Species Update, 19: 232-239.

Kasparek M, Kasparek A, Gözcelioğlu B, Çolak E, Yiğit N. 2004. On the status and distribution of the Striped Hyaena, Hyaena hyaena, in Turkey. Zoology in the Middle East, 33: 93-108. DOI: 10.1080/09397140.2004.10638068.

Koepfli KP, Jenks SM, Eizirik E, Zahirpour T, Van Valkenburgh B, Wayne RK. 2006. Molecular systematics of the Hyaenidae: relationships of a relictual lineage resolved by a molecular supermatrix. Molecular Phylogenetics and Evolution, 38: 603-620. DOI: 10.1016/j.ympev.2005.10.017.

Kruuk H. 1976. Feeding and social behaviour of the striped hyaena (Hyaena vulgaris desmarest). African Journal of Ecology, 14: 91-111.

Kumar S, Stecher G, Tamura K. 2016. MEGA7: molecular evolutionary genetics analysis version 7.0 for bigger datasets. Molecular biology and evolution, 33: 1870-1874. DOI: 10.1093/molbev/msw054.

Librado P, Rozas J. 2009. DnaSP v5: a software for comprehensive analysis of DNA polymorphism data. Bioinformatics, 25: 1451-1452. DOI: 10.1093/bioinformatics/btp187.

Mills MGL Hofer H. 1998. Status survey and conservation action plan. Hyaenas. IUCN/SSC Hyaena Specialist Group, IUCN, Switzerland. ISBN: 2-8317-0442-1

Moritz C. 1994. Applications of mitochondrial DNA analysis in conservation: a critical review. Molecular Ecology, 3: 401411. DOI: 10.1111/j.1365-294X.1994.tb00080.x.

Paijmans JL, Fickel J, Courtiol A, Hofreiter M, Förster DW. 2016. Impact of enrichment conditions on cross-species capture of fresh and degraded DNA. Molecular Ecology Resources, 16: 42-55. DOI: 10.1111/1755-0998.12420.

Palacio P, Berthonaud V, Guérin C, Lambourdière J, Maksud F, Philippe M, Elalouf JM. 2017. Genome data on the extinct Bison schoetensacki establish it as a sister species of the extant European bison (Bison bonasus). BMC Evolutionary Biology, 17: 48.

Prater SH. 1971. The book of Indian animals. Bombay Natural History Society, Oxford University Press, Bombay. ISBN: 9780195621693, 9780195621693

Presa P, Pérez M, Diz AP. 2002. Polymorphic microsatellite markers for blue mussels (Mytilus spp.). Conservation Genetics, 3: 441-443.

Rohland N, Pollack JL, Nagel D, Beauval C, Airvaux J, Pääbo S, Hofreiter M. 2005. The population history of extant and extinct hyaenas. Molecular Biology and Evolution, 22: 24352443. DOI: $10.1093 / \mathrm{molbev} / \mathrm{msi} 244$. 
Schramme E. 2015. Social structure of spotted hyaena (Crocuta crocuta) populations around Mekelle city in Tigrey, Ethiopia (Doctoral dissertation, Universiteit Antwerpen).

Simpson GG. 1953. The major features of evolution (No. 575 S55). ISBN: 0671231030, 978- 0671231033

Şekercioğlu ÇH, Anderson S, Akçay E, Bilgin R, Can ÖE, Semiz G, Sağlam İK. 2011. Turkey's globally important biodiversity in crisis. Biological Conservation, 144: 2752-2769. DOI: 10.1016/j.biocon.2011.06.025.

Wagner AP. 2007. Hyaena hyaena. In The Mammals of Africa. (Amsterdam: Academic Press).

Watts HE, Holekamp KE. 2007. Hyaena societies. Current Biology, 17: R657-R660.

Werdelin L, Solounias N. 1991. The Hyaenidae: taxonomy, systematics and evolution. Fossils and Strata, 30: 1-104.
Westbury MV, De Cahsan B, Dalerum F, Norén K, Hofreiter M. 2019. Aardwolf population diversity and phylogenetic positioning inferred using complete mitochondrial genomes. African Journal of Wildlife Research, 49: 27-33. DOI: 10.3957/056.049.0027.

Westbury MV, Hartmann S, Barlow A, Wiesel I, Leo V, Welch R, Hofreiter M. 2018. Extended and continuous decline in effective population size results in low genomic diversity in the world's rarest hyaena species, the brown hyaena. Molecular biology and evolution, 35: 1225-1237. DOI: 10.1093/molbev/msy037.

Yu JN, Kim S, Oh K, Kwak M. 2012. Complete mitochondiral genome of the Korean red fox Vulpes vulpes (Carnivora, Canidae). Mitochondrial DNA, 23: 118-119. DOI: 10.3109/19401736.2011.653800.

Zhang DX, Hewitt GM. 1997. Insect mitochondrial control region: a review of its structure, evolution and usefulness in evolutionary studies. Biochemical Systematics and Ecology, 25: 99-120. 